\title{
Specific Functions of Red, Far Red, and Blue Light in Flowering and Stem Extension of Long-day Plants
}

\author{
Erik S. Runkle and Royal D. Heins ${ }^{1}$ \\ Department of Horticulture, Michigan State University, East Lansing, MI 48824-1325
}

\begin{abstract}
AdDitional INDEX words. Campanula carpatica, Coreopsis $\times$ grandiflora, Lobelia $\times$ speciosa, phytochrome, Pisum sativum, spectral filters, Viola $\times$ wittrockiana

Abstract. For many long-day plants (LDP), adding far red light (FR, 700 to $800 \mathrm{~nm})$ to red light (R, 600 to $700 \mathrm{~nm})$ to extend the day or interrupt the night promotes extension growth and flowering. Blue light $(B, 400$ to $500 \mathrm{~nm})$ independently inhibits extension growth, but its effect on flowering is not well described. Here, we determined how R-, FR-, or B-deficient $\left(R_{d}, \mathbf{F} R_{d}\right.$, or $B_{\mathrm{d}}$, respectively) photoperiods influenced stem extension and flowering in five LDP species: Campanula carpatica Jacq., Coreopsis $\times$ grandiflora Hogg ex Sweet, Lobelia Xspeciosa Sweet, Pisum sativum L., and Viola Xwittrockiana Gams. Plants were exposed to $R_{d}, F R_{d}, B_{d}$, or normal (control) 16-hour photoperiods, each of which had a similar photosynthetic (400 to $700 \mathrm{~nm}$ ) photon flux. Compared with that of the control, the $\mathbf{R}_{\mathrm{d}}$ environment promoted extension growth in $C$. carpatica

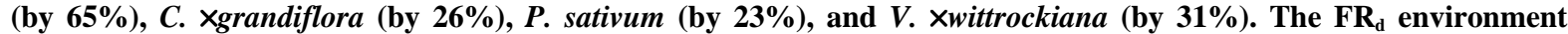
suppressed extension growth in $C$. Xgrandiflora (by 21\%), P. sativum (by 17\%), and V. Xwittrockiana (by $14 \%$ ). Independent of the $R:$ FR ratio, the $B_{d}$ environment promoted stem extension (by $10 \%$ to $100 \%$ ) in all species, but there was little or no effect on flowering percentage and time to flower. Extension growth was generally linearly related to the incident wide band $(100 \mathrm{~nm}) \mathrm{R}:$ FR ratio or estimated phytochrome photoequilibrium except when $B$ light was specifically reduced. A high $R$ : FR ratio (i.e., under the $F_{d}$ filter) delayed flower initiation (but not development) in $C$. carpatica and $C$. Xgrandiflora and inhibited flower development (but not initiation) in $V . \times$ wittrockiana. Therefore, B light and the $R$ : FR ratio independently regulate extension growth by varying magnitudes in LDP, and in some species, an FR environment can suppress flower initiation or development.
\end{abstract}

Plants detect light quality by at least three families of photoreceptors: phytochromes, cryptochromes, and one or more unidentified ultraviolet light receptor(s). Phytochrome absorbance peaks are in the red (R, 600 to $700 \mathrm{~nm})$ and far red (FR, 700 to 800 $\mathrm{nm}$ ) light, and to a lesser extent in blue (B, 400 to $500 \mathrm{~nm}$ ) light. For any one phytochrome, there exists a photoequilibrium of two interconvertible forms: the R and FR absorbing forms, which are known as $P_{r}$ and $P_{f r}$, respectively. $P_{f r}$ is considered to elicit physiological responses but $\mathrm{P}_{\mathrm{r}}$ could be the active form of phytochrome A (Shinomura et al., 2000). In addition, intermediate short-lived forms between $\mathrm{P}_{\mathrm{r}}$ and $\mathrm{P}_{\mathrm{fr}}$ exist.

Depending on light quality, a phytochrome photoequilibrium $\left(\mathrm{P}_{\mathrm{fr}} / \mathrm{P}\right.$, where $\left.\mathrm{P}=\mathrm{P}_{\mathrm{r}}+\mathrm{P}_{\mathrm{fr}}\right)$ is established, where a high $\mathrm{R}$ : FR ratio creates a high $\mathrm{P}_{\mathrm{fr}} / \mathrm{P}$, and vice versa. Models to estimate the $\mathrm{P}_{\mathrm{fr}} / \mathrm{P}$ have been developed (Hayward, 1984; Sager et al., 1988) based on the distribution of incident spectral radiation from 300 to 800 $\mathrm{nm}$. These models are based on cross-section phytochrome A data from etiolated oats (Avena sativa $\mathrm{L}$.), but its validity in estimating $\mathrm{P}_{\mathrm{fr}} / \mathrm{P}$ in light-grown plants or for other phytochromes is unknown. Nevertheless, these estimates and R : FR ratios are useful in associating photomorphogenic responses with light quality (Smith, 1994).

In addition to phytochromes, B light is absorbed by cryptochromes. Cryptochromes participate in inhibition of stem extension, particularly those in Brassicaceae (Kigel and Cosgrove, 1991). The suppression of extension growth by B light has been

\footnotetext{
Received for publication 17 July 2000. Accepted for publication 1 Feb. 2001. We gratefully acknowledge support of the Michigan Agricultural Experiment Station and funding by project GREEEN and greenhouse growers supportive of Michigan State University floricultural research. We also thank Dan Tschirhart for greenhouse assistance and Simon Pearson and British Visqueen for the experimental FR filter. The cost of publishing this paper was defrayed in part by the payment of page charges. Under postal regulations, this paper therefore must be hereby marked advertisement solely to indicate this fact.

${ }^{1}$ Corresponding author; e-mail: heins@msu.edu.
}

well documented, especially in hypocotyls and epicotyls (Casal and Smith, 1989; Laskowski and Briggs, 1989; Liscum et al., 1992; Warpeha and Kaufman, 1989). In addition to inhibiting stem extension, B light participates in flower induction in some long-day plants (LDP), such as Hyoscyamus niger L. (Schneider et al., 1967; Stolwijk and Zeevaart, 1955) and Arabidopsis thaliana Heynh. (Bagnall et al., 1996; Lin et al., 1996; Mozley and Thomas 1995). Some of the cryptochrome effects are independent of phytochrome, while others are conditionally interactive (Casal and Mazzella, 1998; Poppe et al., 1998). Compared with data on phytochrome, however, relatively little is known about how B light regulates flowering.

Plants are classified by their photoperiodic flowering response [e.g., short-day plants (SDP) or LDP]. Alternatively, plants that are controlled primarily by light or dark processes can be classified as light- or dark-dominant plants, respectively (Thomas and Vince-Prue, 1997). Most light- and dark-dominant plants are LDP and SDP, respectively, but some exceptions exist. Lightdominant LDP show two general characteristics: 1) a quantitative relationship exists between the irradiance of the night break and the magnitude of the flowering response, until a saturation light intensity, duration, or both, are reached; 2) flowering is often most rapid when photoperiods contain some minimal amount of FR. In contrast, flowering of dark-dominant plants can be regulated by a short night break (e.g., $\leq 30 \mathrm{~min}$ ) containing little or no FR light.

Artificial long days (LD) can be created by lighting at the end of the natural photoperiod or by interrupting the dark period with a light break. Flowering of LDP is promoted most when artificial lighting contains $\mathrm{R}$ and FR (creating a moderately low $\mathrm{P}_{\mathrm{fr}} / \mathrm{P}$ ) compared with light deficient in FR (creating a high $\mathrm{P}_{\mathrm{fr}} / \mathrm{P}$; Downs and Thomas, 1982; Lane et al., 1965). However, extension growth of a wide range of species shows an inverse linear relationship with estimated $\mathrm{P}_{\mathrm{fr}} / \mathrm{P}$ (Smith, 1982, 1994). Therefore, incident light creating a moderately low $\mathrm{P}_{\mathrm{fr}} / \mathrm{P}$ simultaneously 
promotes flowering and stem extension, and that creating a high $\mathrm{P}_{\mathrm{fr}}$ $\mathrm{P}$ is inhibitory to both responses.

Plastic filters that selectively reduce transmission of $\mathrm{R}$ light have been used experimentally to promote extension growth in various herbaceous plants (Kubota et al., 2000; Murakami et al., 1996; Rajapakse et al., 1999). To limit stem extension, flexible plastic filters have been developed to reduce transmission of FR radiation (Oyaert et al., 1999; Rajapakse et al., 1999; van Haeringen et al., 1998). These $F_{d}$ filters have reduced extension growth in a variety of species, including vegetables and ornamental plants. However, an $\mathrm{FR}_{\mathrm{d}}$ environment can delay flowering in some plants, but in many reports, this delay has not been addressed.

The primary objective of this research was to determine how flowering and stem extension in LDP were regulated by photoperiods deficient in R, FR, and B. First, specific wave band effects were identified by comparing plant responses under photoselective filters with those under a neutral $(\mathrm{N})$ filter that transmitted a similar photosynthetic photon flux $(P P F)$. Two subsequent experiments were performed to further quantify how light deficient in FR regulated flower initiation and development. These studies illustrate the variability in species' responses to light quality and underscore the complexity of how light regulates flowering and stem extension in LDP. In addition, while an $\mathrm{FR}_{\mathrm{d}}$ environment can suppress extension growth in plants, it can also delay flowering in some LDP.

\section{Materials and Methods}

\section{Stem extension and flowering under photoselective filters (Expt. 1)}

Plant material. Seeds of Campanula carpatica 'Blue Clips', Coreopsis $\times$ grandiflora 'Early Sunrise', and Lobelia $\times$ speciosa 'Compliment Scarlet' were sown into 128-cell (10-mL) plug trays and that of Viola $\times$ wittrockiana 'Crystal Bowl Yellow' into 288-cell (6-mL) plug trays by a wholesale plug producer (Rakers Acres,
Litchfield, Mich.). Seedlings were grown under photoperiods $\leq 12$ $\mathrm{h}$ at $22.0 \pm 2{ }^{\circ} \mathrm{C}$. Pisum sativum 'Utrillo' seed were sown into 50-cell (85-mL) plug trays. Seeding, shipping, and forcing (the onset of treatments) dates are provided in Table 1. Plants were thinned to one per plug and held at $20^{\circ} \mathrm{C}$ until plugs were mature. At the onset of experiments, plants were transplanted into 13-cm (1.1-L) square plastic containers and node counts were recorded (Table 1).

Plant culture. Plants were grown in a commercial soilless medium composed of composted pine bark, vermiculite, Canadian sphagnum peat, coarse perlite with a wetting agent, and lime (High Porosity Mix; Strong-Lite Products, Pine Bluff, Ark.). Plants were fertilized at every irrigation with a nutrient solution of well water acidified with $\mathrm{H}_{2} \mathrm{SO}_{4}$ to a titratable alkalinity of $\approx 130 \mathrm{mg} \mathrm{CaCO}_{3} \cdot \mathrm{L}^{-1}$ and water soluble fertilizer $\left[125 \mathrm{~N}-12 \mathrm{P}-125 \mathrm{~K}\left(\mathrm{mg} \cdot \mathrm{L}^{-1}\right)\right.$ plus $1.0 \mathrm{Fe}-$ $0.5 \mathrm{Mn}-0.5 \mathrm{Zn}-0.5 \mathrm{Cu}-0.1 \mathrm{~B}-0.1 \mathrm{Mo}\left(\mathrm{mg} \cdot \mathrm{L}^{-1}\right.$; MSU Special, Greencare Fertilizers, Chicago, Ill.)].

LIGHTING AND FILTER TREATMENTS. A reciprocal transfer experiment with four different light quality environments was conducted using a neutral $(\mathrm{N})$ density metalized woven fabric or plastics that selectively reduced the transmission of $B\left(B\right.$ deficient, $\left.B_{d}\right), R(R$ deficient, $R_{d}$ ), or FR (FR deficient, $F_{d}$ ) light. Filter treatments were designed to transmit a similar $P P F$. The following filters (one layer each) enclosed greenhouse benches to provide the light quality treatments: N, OLS50 (Ludvig Svensson, Charlotte, N.C.) + PLS Clear (Ludvig Svensson); $\mathrm{B}_{\mathrm{d}}$, Lee filter 101 (Andover, United Kingdom) + OLS40 (Ludvig Svensson); $\mathrm{R}_{\mathrm{d}}$, Lee filter $115 ; \mathrm{FR}_{\mathrm{d}}$, experimental FR filter (van Haeringen et al., 1998) + PLS Clear. Solar spectra transmissions from 400 to $800 \mathrm{~nm}$ were measured under filters by a spectroradiometer (LI-1800, LI-COR, Inc., Lincoln, Nebr.) and are shown in Fig. 1. Quantum ratios (R : FR, B : R, and $B: F R)$, the estimated $P_{f r} / P($ Sager et al., 1988), and the relative quantum efficiency (McCree, 1972) were quantified for each light treatment (Table 2).

Twenty plants of each species were placed $(\approx 8 \mathrm{~cm}$ apart $)$ under

Table 1. Seed, shipping, and forcing dates, initial node counts, and average air temperature and photosynthetic daily light integral during experiments. Environmental data were calculated from date of forcing to average date of visible bud (Expt. I), average date of flowering (Expt. III), or 144 $\mathrm{d}$ from forcing (Expt. II) under each treatment. $\mathrm{N}=$ neutral-density; $\mathrm{R}_{\mathrm{d}}=$ red $(600$ to $700 \mathrm{~nm})$ deficient; $\mathrm{B}_{\mathrm{d}}=$ blue $(400$ to $500 \mathrm{~nm})$ deficient; FR $=$ far-red $(700$ to $800 \mathrm{~nm})$ deficient; NA = not applicable; - (long dash $)=$ incomplete data.

\begin{tabular}{|c|c|c|c|c|c|c|c|c|c|c|c|c|c|}
\hline \multirow[b]{2}{*}{ Expt. and species } & \multirow[b]{2}{*}{ Rep. } & \multicolumn{3}{|c|}{ Date } & \multirow{2}{*}{$\begin{array}{l}\text { Initial } \\
\text { nodes }\end{array}$} & \multirow{2}{*}{\multicolumn{3}{|c|}{$\begin{array}{c}\text { Avg air temp } \\
\text { during forcing } \\
\left({ }^{\circ} \mathrm{C}\right)\end{array}$}} & & \multirow{2}{*}{\multicolumn{4}{|c|}{$\begin{array}{c}\text { Avg daily } \\
\text { light integral } \\
\text { during forcing } \\
\left(\mathrm{mol} \cdot \mathrm{m}^{-2} \cdot \mathrm{d}^{-1}\right)\end{array}$}} \\
\hline & & \multirow[t]{2}{*}{ Seed } & \multirow[t]{2}{*}{ Shipping } & \multirow[t]{2}{*}{ Forcing } & & & & & & & & & \\
\hline & & & & & & \multicolumn{8}{|c|}{ Light environment } \\
\hline Expt. I & & & & & & $\mathrm{N}$ & $\mathrm{R}_{\mathrm{d}}$ & $\mathrm{FR}_{\mathrm{d}}$ & $\mathrm{B}_{\mathrm{d}}$ & $\mathrm{N}$ & $\mathrm{R}_{\mathrm{d}}$ & $\mathrm{FR}_{\mathrm{d}}$ & $\mathrm{B}_{\mathrm{d}}$ \\
\hline \multirow[t]{2}{*}{ Campanula carpatica } & 1 & 20 July 1998 & 26 Sept. 1998 & 29 Oct. 1998 & 8.3 & 20.2 & 20.3 & 20.0 & 19.9 & 4.5 & 3.8 & 4.0 & 3.7 \\
\hline & 2 & 30 Nov. 1998 & 31 Dec. 1998 & 22 Feb. 1999 & 11.0 & 20.7 & 21.1 & 20.0 & 20.4 & 6.4 & 5.8 & 6.6 & 6.0 \\
\hline \multirow[t]{2}{*}{ Coreopsis $\times$ grandiflora } & $a 1$ & 11 May 1998 & 29 May 1998 & 9 July 1998 & 6.1 & 22.3 & 22.7 & 22.5 & 22.1 & 5.3 & 5.8 & 5.0 & 5.0 \\
\hline & 2 & 31 Aug. 1998 & 19 Sept. 1998 & 21 Oct. 1998 & 5.8 & 20.2 & 20.4 & 20.2 & 20.0 & 4.8 & 4.0 & 4.3 & 4.2 \\
\hline \multirow[t]{2}{*}{ Lobelia $\times$ speciosa } & 1 & 18 May 1998 & 12 June 1998 & 9 July 1998 & 5.9 & 22.5 & 22.5 & 22.6 & 22.4 & 5.7 & 5.9 & 4.7 & 5.2 \\
\hline & 2 & 31 Aug. 1998 & 26 Sept. 1998 & 3 Nov. 1998 & 6.3 & 20.3 & 20.5 & 20.0 & 20.1 & 4.3 & 3.8 & 4.0 & 3.8 \\
\hline \multirow[t]{2}{*}{ Pisum sativum } & 1 & 19 June 1998 & --- & 9 July 1998 & 5.5 & 22.2 & 22.3 & 22.2 & 22.2 & 5.9 & 4.5 & 4.8 & 6.4 \\
\hline & 2 & 10 Aug. 1998 & --- & 30 Aug. 1998 & 6.1 & 21.3 & 21.4 & 21.5 & 21.2 & 5.7 & 6.0 & 6.1 & 6.3 \\
\hline \multirow[t]{2}{*}{ Viola $\times$ wittrockiana } & 1 & 15 June 1998 & 14 July 1998 & 18 July 1998 & 4.0 & 22.3 & 22.7 & 22.6 & 22.6 & --- & --- & --- & --- \\
\hline & 2 & 20 July 1998 & 18 Aug. 1998 & 24 Aug. 1998 & 4.0 & 21.8 & 22.2 & 21.9 & 22.2 & 5.9 & 6.8 & 6.4 & 6.6 \\
\hline \multicolumn{14}{|l|}{ Expt. II } \\
\hline \multirow[t]{2}{*}{ Viola $\times$ wittrockiana } & & 28 Oct. 1998 & 2 Nov. 1998 & 9 Nov. 1998 & 1.0 & 20.1 & $\mathrm{NA}$ & 20.1 & NA & 4.8 & NA & 4.9 & NA \\
\hline & & & & & & \multicolumn{8}{|c|}{ Weeks at high DLI } \\
\hline \multicolumn{2}{|l|}{ Expt. III } & & & & & 0 & 2 & 3 & 4 & 0 & 2 & 3 & 4 \\
\hline \multicolumn{2}{|l|}{ Coreopsis $\times$ grandiflora } & 30 Nov. 1998 & 1 Jan. 1999 & 29 Jan. 1999 & 4.8 & 20.3 & 20.6 & 20.7 & 20.7 & 5.7 & 7.5 & 8.5 & 9.6 \\
\hline
\end{tabular}




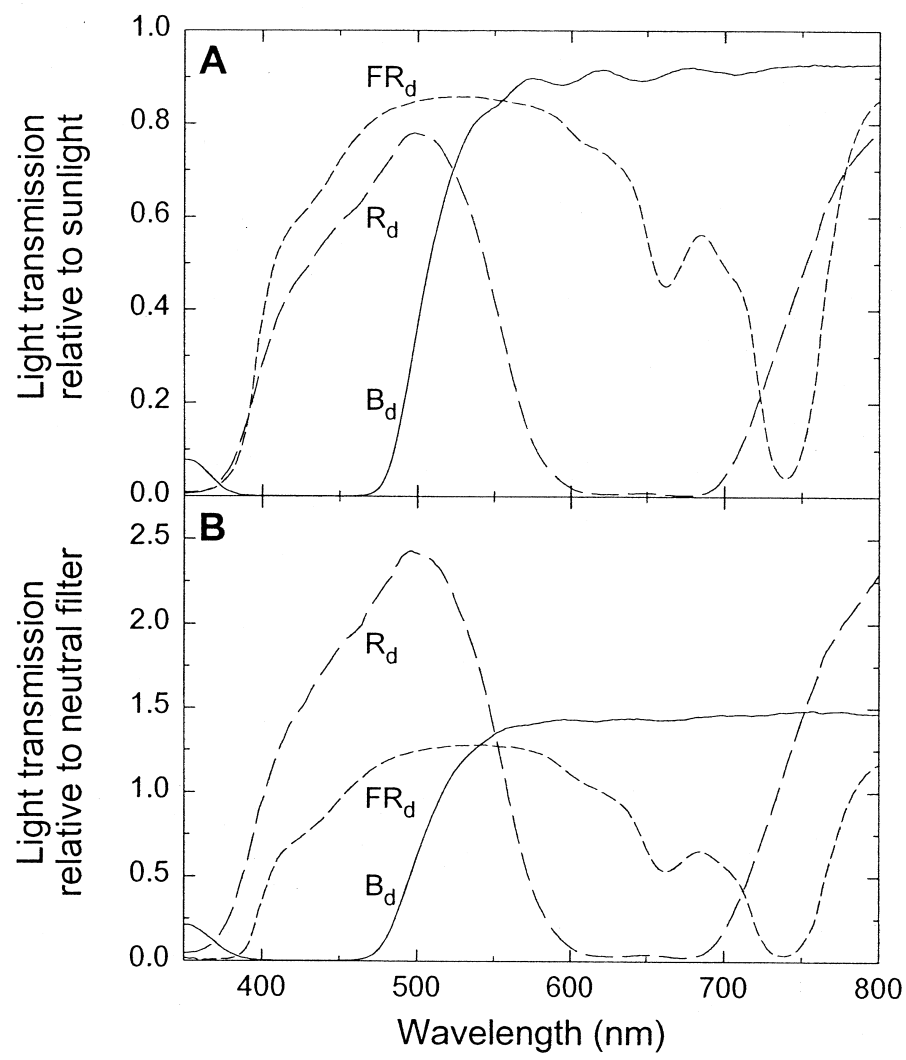

Fig. 1. Spectral transmissions of photoselective filters relative to (A) sunlight or (B) that under the neutral-density filter treatment with an equal photosynthetic photon flux. $R_{d}$, red $(600$ to $700 \mathrm{~nm})$ deficient filter; $B_{\mathrm{d}}$, blue $(400$ to $500 \mathrm{~nm})$ deficient filter; $\mathrm{FR}_{\mathrm{d}}$, far red $(700$ to $800 \mathrm{~nm}$ ) deficient filter. See Table 2 for light wave band ratios.

each of the $\mathrm{B}_{\mathrm{d}}, \mathrm{R}_{\mathrm{d}}$, and $\mathrm{FR}_{\mathrm{d}}$ treatments, and 40 under the $\mathrm{N}$ filter. When flower buds were visible [visible bud (VB)], 10 plants under the $B_{d}, R_{d}$, and $F_{d}$ environments were transferred to the $N$ light treatment, and 10 were transferred at VB from the $\mathrm{N}$ environment to each other light environments. Filter effects on flowering and stem extension before and after flower initiation could thus be separated. The experiment was performed twice.

A 16-h photoperiod was provided with a combination of sunlight and high-pressure sodium (HPS) lamps positioned above filters. From 0600 to $2200 \mathrm{HR}$, HPS lamps provided at plant level a supplemental $P P F$ of $\approx 35 \mu \mathrm{mol} \cdot \mathrm{m}^{-2} \cdot \mathrm{s}^{-1}$ when the ambient greenhouse $P P F$ was $<200 \mu \mathrm{mol} \cdot \mathrm{m}^{-2} \cdot \mathrm{s}^{-1}$ and were shut off when the ambient $P P F$ was $>400 \mu \mathrm{mol} \cdot \mathrm{m}^{-2} \cdot \mathrm{s}^{-1}$. The light quantum ratios under the filters were calculated at night when the lamps were the only light source (Table 2). Under each filter treatment, the average photosynthetic daily light integral (DLI) was measured at canopy level with line quantum sensors that included 18 photodiodes
(G2711; Hamamatsu Co., Hamamatsu, Japan) connected to a datalogger (CR10; Campbell Scientific, Logan, Utah). Each line quantum sensor was independently calibrated under the filters by using the spectroradiometer (Table 1).

GREENHOUSE TEMPERATURE CONTROL. All plants were grown in a glass greenhouse at $20^{\circ} \mathrm{C}$. Air temperatures under each filter treatment were monitored with 36-gauge (0.127-mm-diameter) type E thermocouples connected to dataloggers (CR10; Campbell Scientific). To provide uniform night temperatures, dataloggers were used to control $1500-\mathrm{W}$ electric heaters under each bench, which provided supplemental heat as needed throughout the night. To improve temperature uniformity under filters during the day, dataloggers were used to control portable fans to vent each bench as needed. The dataloggers collected temperature data every $10 \mathrm{~s}$ and recorded the hourly averages. For each experiment, average daily air temperatures from the beginning of treatment until the average date of VB under each filter were calculated (Table 1).

DATA COLLECTION AND ANALYSIS. Experiments were replicated in time and were arranged in a completely randomized design. The date the first flower bud was visible (without dissection) and the date the first flower reached anthesis (flowering) were recorded for each plant. At flowering, visible flower buds or inflorescences and nodes on the main stem were counted. Except for $V$. $\times$ wittrockiana, plant height (from soil level to the top of inflorescence) at VB was measured. Total plant height at flowering was measured for all species except $P$. sativum. Plants were considered nonflowering if flower buds were not visible after 32 or $63 \mathrm{~d}$ of treatments for $P$. sativum and $V$. $\times$ wittrockiana, respectively, and after 15 weeks for C. carpatica, $C . \times$ grandiflora, and $L$. $\times$ speciosa. Leaves and stems of $P$. sativum were weighed after $32 \mathrm{~d}$ of treatments, and dry weight (DW) was measured following $2 \mathrm{~d}$ at $55^{\circ} \mathrm{C}$. Days to VB, days from VB to flower, days to flower, and node-count increase from the start of treatments were calculated. Data were subjected to analysis of variance (ANOVA) using general linear models (GLM) procedures of SAS (SAS Institute, Inc., Cary, N.C.) and a SAS mean separation procedure for unequal observation numbers (pdiff) with $P=0.05$. Unless otherwise stated, all comparisons made are relative to responses under the $\mathrm{N}$ filter.

\section{Viola reciprocal transfer (Expt. 2)}

A separate experiment was performed with $V$. ×wittrockiana 'Crystal Bowl Yellow' to determine how plant age influenced the flowering inhibition under the $\mathrm{FR}_{\mathrm{d}}$ filter. Plants were placed under the $\mathrm{N}$ and $\mathrm{FR}_{\mathrm{d}}$ filters, then were transferred to the other filter after 5 , $10,15,20,25,30,35$, or $40 \mathrm{~d}$. The corresponding average node numbers at transfer times were 1.9, 2.8, 4.0, 5.0, 5.9, 6.9, 7.3, and 8.8. Experimental conditions were as described above unless otherwise stated. Seeding, shipping, and forcing dates, average temperatures, and DLI are provided in Table 1. The following data were recorded: date of flowering (anthesis), node count increase to the first VB and

Table 2. Quantum ratios of red (R), far red (FR), and blue (B) light, calculated phytochrome photoequilibria $\left(\mathrm{P}_{\mathrm{fr}} / \mathrm{P}\right)$, and relative quantum efficiency (RQE) under filters with sun or high-pressure sodium (HPS) lamps as the sole light source (McCree, 1972; Sager et al., 1988). B = 400 to 500 $\mathrm{nm} ; \mathrm{FR}=700$ to $800 \mathrm{~nm} ; \mathrm{FR}_{\mathrm{n}}=\mathrm{FR}$ narrow band width $(725$ to $735 \mathrm{~nm}) ; \mathrm{R}=600$ to $700 \mathrm{~nm} ; \mathrm{R}_{\mathrm{n}}=\mathrm{R}$ narrow band width $(655$ to $665 \mathrm{~nm})$.

\begin{tabular}{|c|c|c|c|c|c|c|c|c|c|c|c|}
\hline \multirow[b]{3}{*}{ Filter } & \multicolumn{11}{|c|}{ Light source } \\
\hline & \multicolumn{6}{|c|}{ Sun } & \multicolumn{5}{|c|}{ HPS lamps } \\
\hline & $\mathrm{R}_{\mathrm{n}}: \mathrm{FR}_{\mathrm{n}}$ & $\mathrm{R}: \mathrm{FR}$ & $\mathrm{B}: \mathrm{R}$ & $\mathrm{B}: \mathrm{FR}$ & $\mathrm{P}_{\mathrm{fr}} / \mathrm{P}$ & $\overline{\mathrm{RQE}}$ & $\mathrm{R}_{\mathrm{n}}: \mathrm{FR}_{\mathrm{n}}$ & $\mathrm{R}: \mathrm{FR}$ & $\mathrm{B}: \mathrm{R}$ & $\mathrm{B}: \mathrm{FR}$ & $\mathrm{P}_{\mathrm{ft}} / \mathrm{P}$ \\
\hline Neutral & 1.06 & 1.07 & 0.75 & 0.81 & 0.715 & 0.889 & 2.82 & 3.98 & 0.17 & 0.69 & 0.850 \\
\hline $\mathrm{R}_{\mathrm{d}}$ & 0.04 & 0.04 & 30.72 & 1.16 & 0.399 & 0.785 & 0.12 & 0.15 & 7.16 & 1.05 & 0.624 \\
\hline $\mathrm{FR}_{\mathrm{d}}$ & 8.22 & 1.74 & 0.94 & 1.63 & 0.798 & 0.849 & 9.96 & 5.73 & 0.15 & 0.86 & 0.873 \\
\hline $\mathrm{B}_{\mathrm{d}}$ & 1.04 & 1.05 & 0.06 & 0.06 & 0.723 & 0.934 & 2.74 & 3.82 & 0.02 & 0.09 & 0.851 \\
\hline
\end{tabular}




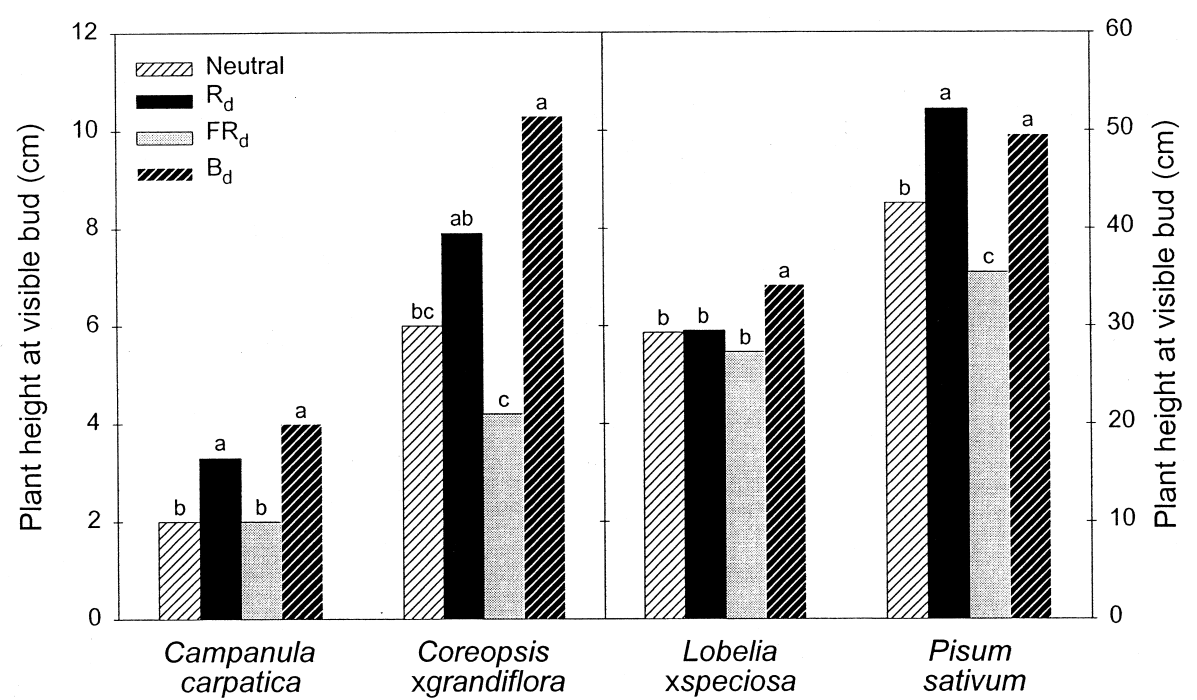

Fig. 2. Plant height at visible bud of Campanula carpatica, Coreopsis $\times$ grandiflora, Lobelia $\times$ speciosa, and Pisum sativum under a neutral filter or a light environment deficient in red $\left(R_{d}, 600\right.$ to $\left.700 \mathrm{~nm}\right)$, far red $\left(\mathrm{FR}_{\mathrm{d}}, 700\right.$ to $\left.800 \mathrm{~nm}\right)$, or blue $\left(\mathrm{B}_{\mathrm{d}}\right.$, 400 to $500 \mathrm{~nm}$ ). A 16-h photoperiod was provided with a combination of sunlight and high-pressure sodium lamps positioned above filters. Values ( $\mathrm{n}=$ 20 for Pisum and 40 to 80 for other species) with the same letter within species are not statistically different at $P=0.05$.

first open flower, and whether first flowering was on the primary or an axillary shoot. Flowering percentage, days to flower, node-count increase to the first VB and flowering, undeveloped buds below the first open flower, and axillary flowering percentage were calculated. The experiment was terminated 21 weeks after initiation.

\section{Coreopsis transfer (Expt. 3)}

Only approximately half of the $C$. $\times$ grandiflora flowered in Expt. 1. We attributed the low flowering percentage to the relatively low DLI provided to plants. Therefore, a third experiment was performed to determine if plants could be induced under naturally high light then transferred to the $\mathrm{N}$ or $\mathrm{FR}_{\mathrm{d}}$ filters until flowering. Plants were grown under unfiltered, natural photoperiods supplemented from 0600 to $2200 \mathrm{HR}$ with HPS lamps (as described above) but with a $P P F \approx 100 \mu \mathrm{mol} \cdot \mathrm{m}^{-2} \cdot \mathrm{s}^{-1}$. After $0,2,3$, and 4 weeks under high light, 10 plants were transferred to the $\mathrm{N}$ and $\mathrm{FR}_{\mathrm{d}}$ filters until flowering. Experimental conditions were as described above unless otherwise stated. Seeding, shipping, and forcing dates and average temperature and DLI from forcing to flowering are provided in Table 1. The dates of VB and flowering were recorded. At flowering, visible flower buds and nodes on the main stem were counted and total plant height was measured. Flowering percentage, days to flower, and node-count increase to flowering were calculated.

\section{Results}

\section{Stem extension and flowering under photoselective filters (Expt. 1)}

STEM EXtension. The $\mathrm{R}_{\mathrm{d}}$ environment increased plant height from forcing to $\mathrm{VB}$ by $65 \%$ in C. carpatica and $23 \%$ in P. sativum

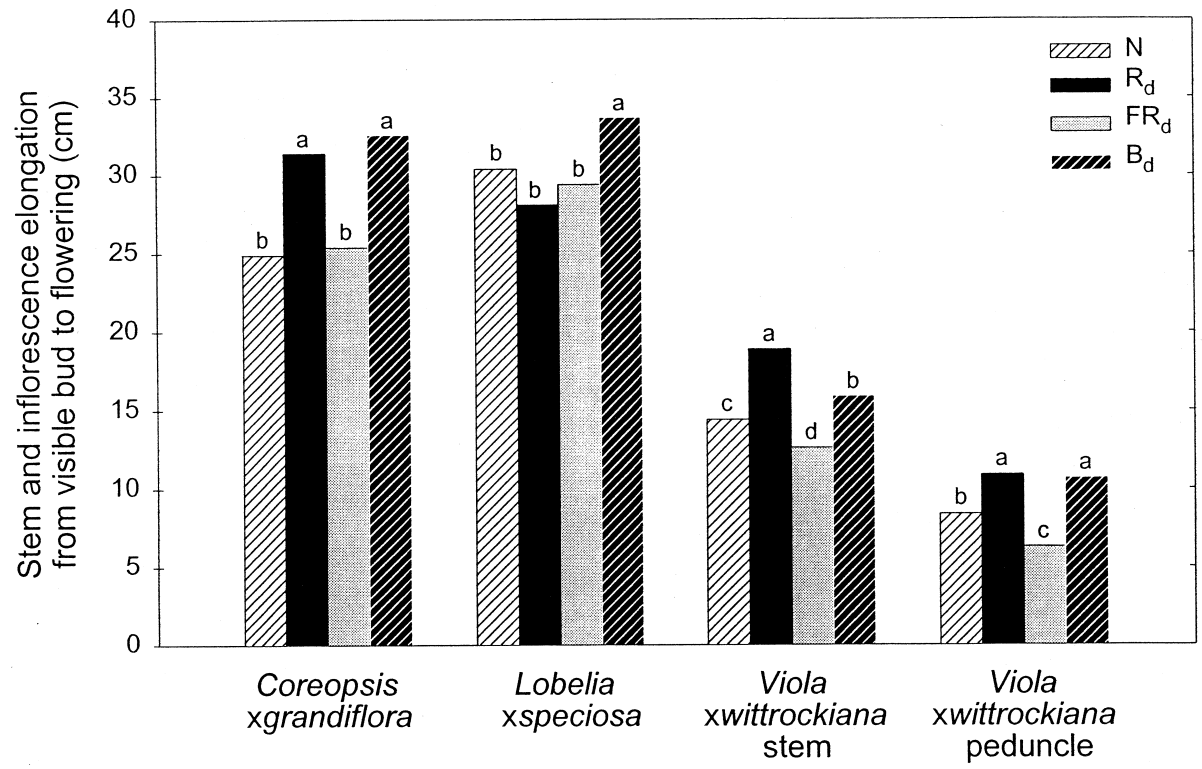

compared with that in the $\mathrm{N}$ environment (Fig. 2). The $\mathrm{B}_{\mathrm{d}}$ environment promoted internode elongation in all species studied. Compared with that under the $\mathrm{N}$ filter, the $\mathrm{B}_{\mathrm{d}}$ filter increased stem length from forcing until VB by $100 \%, 72 \%, 17 \%$, and $16 \%$ in C. carpatica, C. × grandiflora, L. ×speciosa, and P. sativum, respectively.

The $\mathrm{R}_{\mathrm{d}}$ treatment increased stem and inflorescence elongation from $\mathrm{VB}$ to flowering by $26 \%$ or $30 \%$ in $C$. $\times$ grandiflora and $V$. $\times$ wittrockiana, respectively (Fig. 3 ). The $\mathrm{FR}_{\mathrm{d}}$ filter suppressed extension growth in only two species, $P$. sativum (stem length by $20 \%$ ) and $V$. ×wittrockiana (stem and peduncle length by $14 \%$ and $33 \%$, respectively). Changes in R or FR light did not influence stem extension of $L$. $\times$ speciosa. From VB to flowering, the $\mathrm{B}_{\mathrm{d}}$ environment increased stem and inflorescence elongation in $C . \times$ grandiflora, $L . \times$ speciosa, and $V$. $\times$ wittrockiana by $31 \%, 11 \%$, and $10 \%$, respectively. In addition, the $\mathrm{B}_{\mathrm{d}}$ filter increased peduncle length of $V$. $\times$ wittrockiana by $27 \%$.

Flowering. The $\mathrm{FR}_{\mathrm{d}}$ environment inhibited flowering in $V$. $\times$ wittrockiana; $88 \%$ and $65 \%$ of plants under the $\mathrm{FR}_{\mathrm{d}}$ filter reached $\mathrm{VB}$ and flowering, respectively, whereas all plants flowered in the other three light environments (data not presented). The $B_{d}, R_{d}$, and $\mathrm{FR}_{\mathrm{d}}$ environments had no significant effect on flowering percentage of the other species studied. Essentially all C.carpatica, L. $\times$ speciosa, and $P$. sativum reached VB and flowered under all light quality treatments, but irrespective of filter treatment (including that under the $\mathrm{N}$ filter), only $50 \%$ and $42 \%$ of $C$. $\times$ grandiflora reached $\mathrm{VB}$ and anthesis, respectively (data not presented).

Light deficient in R delayed time to VB by 4 or $1 \mathrm{~d}$ in $C$.

Fig. 3. Stem and inflorescence elongation from visible bud to flowering of Coreopsis $\times$ grandiflora, Lobelia $\times$ speciosa, and Viola $\times$ wittrockiana under a neutral filter $(\mathrm{N})$ or a light environment deficient in red $\left(R_{d}, 600\right.$ to $\left.700 \mathrm{~nm}\right)$, far red $\left(\mathrm{FR}_{\mathrm{d}}, 700\right.$ to $\left.800 \mathrm{~nm}\right)$, or blue $\left(\mathrm{B}_{\mathrm{d}}, 400\right.$ to $\left.500 \mathrm{~nm}\right)$. A 16-h photoperiod was provided with a combination of sunlight and high-pressure sodium lamps positioned above filters. Values ( $n=17$ to 39 for Coreposis and 40 to 80 for other species) with the same letter within species and measurement are not statistically different at $P=0.05$. 


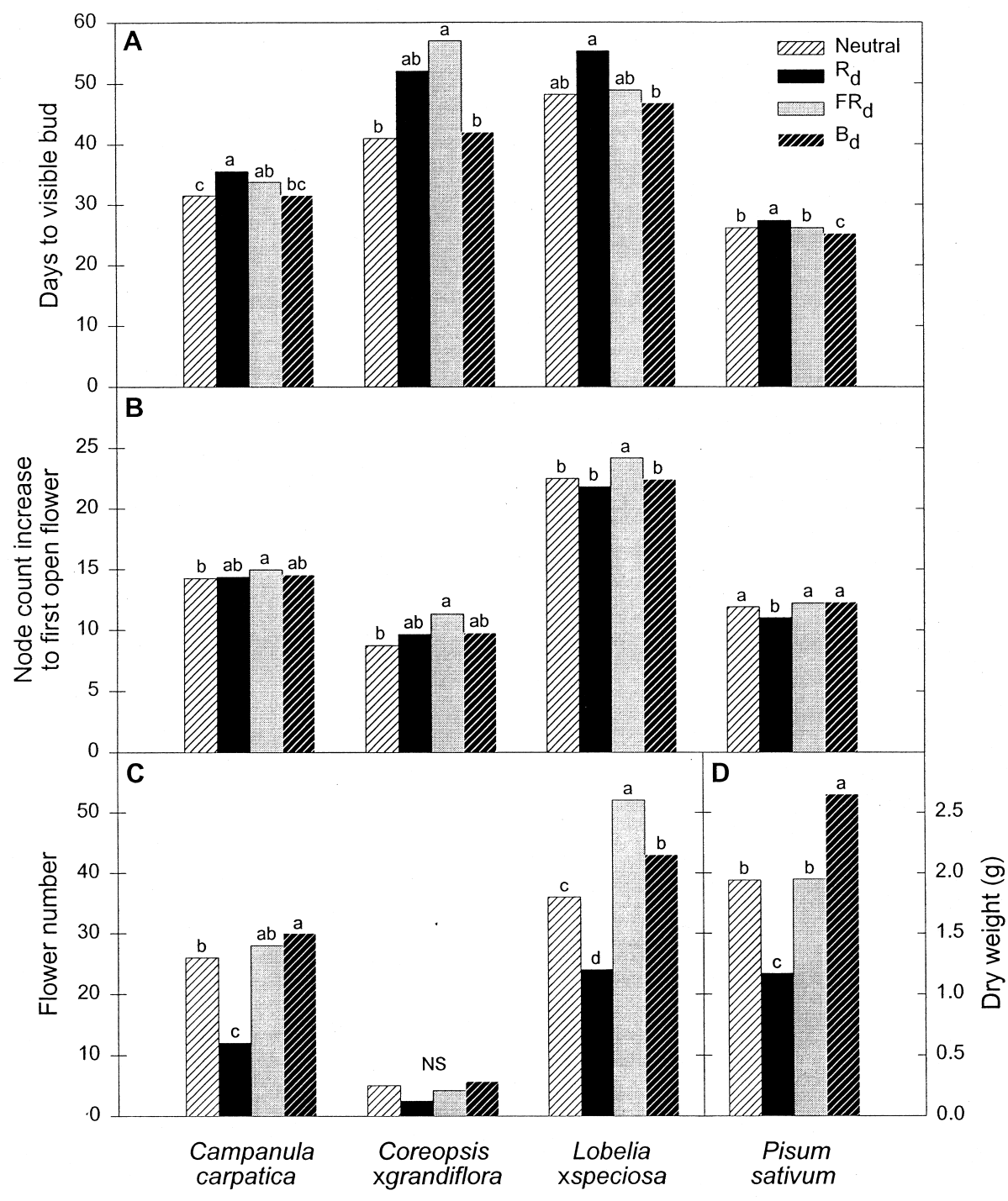

Fig. 4. (A) Days to visible bud, (B) node count increase to first open flower, and (C) flower number or (D) dry weight of Campanula carpatica, Coreopsis $\times$ grandiflora, Lobelia $\times$ speciosa, and Pisum sativum under a neutral filter $(\mathrm{N})$ or a light environment deficient in red $\left(\mathrm{R}_{\mathrm{d}}, 600\right.$ to $\left.700 \mathrm{~nm}\right)$, far red $\left(\mathrm{FR}_{\mathrm{d}}, 700\right.$ to $800 \mathrm{~nm})$, or blue $\left(\mathrm{B}_{\mathrm{d}}, 400\right.$ to $\left.500 \mathrm{~nm}\right)$. A 16-h photoperiod was provided with a combination of sunlight and high-pressure sodium lamps positioned above filters. Values ( $\mathrm{n}=17$ to 39 for Coreposis and 40 to 80 for other species) with the same letter within species are not statistically different at $P=0.05$; ss Nonsignificant.

carpatica and $P$. sativum and hastened it by $4 \mathrm{~d}$ in $V$. $\times$ wittrockiana (Figs. 4A and 5A). However, the delay in time to VB under the $\mathrm{R}_{\mathrm{d}}$ filter was not accompanied by the formation of more nodes before VB appearance in any species (Fig. 4B). The $\mathrm{R}_{\mathrm{d}}$ environment had no effect on time from VB to flowering for any species (data not presented). However, the $\mathrm{R}_{\mathrm{d}}$ treatment reduced flower number by $54 \%$ or $33 \%$ in C. carpatica and L. Xspeciosa, respectively, and reduced dry matter accumulation by $40 \%$ in $P$. sativum (Figs. 4C and D).

The $\mathrm{FR}_{\mathrm{d}}$ environment delayed appearance of VB in C. carpatica by $2 \mathrm{~d}$ and $C$. $\times$ grandiflora by $14 \mathrm{~d}$ (Fig. 4A) and delayed flowering of $V$. $\times$ wittrockiana by $21 \mathrm{~d}$ (Fig. 5B). Viola $\times$ wittrockiana developed an average of 9.1 or 12.4 nodes before flowering under the $\mathrm{N}$ or $\mathrm{FR}_{\mathrm{d}}$ treatments, respectively (significantly different at $P<0.05$; data not presented). In addition, $C$. carpatica and $C$. $\times$ grandiflora developed more nodes before flowering under the $\mathrm{FR}_{\mathrm{d}}$ environment than those under the $\mathrm{N}$ filter (Fig. 4B). The $\mathrm{FR}_{\mathrm{d}}$ environment increased flower number of $L$. Xspeciosa by $44 \%$ but not for any other species (Fig. 4C).

A deficiency in B light hastened time to VB in $P$. sativum (by $1 \mathrm{~d}$ ) and $V$. $\times$ wittrockiana (by $4 \mathrm{~d}$ ) but did not influence node number (Figs. 4A and B, and 5C). The $\mathrm{B}_{\mathrm{d}}$ environment had no effect on VB timing of the other three species. In addition, the $B_{d}$ environment had no effect on time from VB to flowering for any species (data not presented). However, flower number of $C$. carpatica and $L$. $\times$ speciosa and DW of $P$. sativum were significantly greater under the $\mathrm{B}_{\mathrm{d}}$ filter (by $15 \%$, $19 \%$, and $37 \%$, respectively, Figs. 4C and D).

Extension growth of a variety of species shows an inverse linear relationship with estimated $\mathrm{P}_{\mathrm{fr}} / \mathrm{P}$ (Smith, 1982, 1994). Using data in our studies, we compared how extension growth was related to $\mathrm{R}$ : FR ratios and the estimated $\mathrm{P}_{\mathrm{fr}} / \mathrm{P}$ under the filter treatments (Table 2; Fig. 6). Stem or internode length under the $\mathrm{N}, \mathrm{R}_{\mathrm{d}}$, and $\mathrm{B}_{\mathrm{d}}$ environments was compared with that under the $\mathrm{FR}_{\mathrm{d}}$ filter, in which stems were shortest. Using results under the $R_{d}, N$, or $F_{d}$ environments, stem extension was not linearly related to narrow band $(10 \mathrm{~nm}) \mathrm{R}$ : FR ratios (Fig. 6A). However, stem extension was linearly related to a wide band (100 nm) R : FR ratio (Fig. 6B) or estimated $\mathrm{P}_{\mathrm{fr}} / \mathrm{P}$ (Fig. 6C). The promotion of stem extension in the $\mathrm{B}_{\mathrm{d}}$ environment did not fit any of the relationships.

\section{Viola reciprocal transfer (Expt. 2)}

All $V$. ×wittrockiana flowered under the $\mathrm{N}$ filter, in an average of $83 \mathrm{~d}$. Under the $\mathrm{FR}_{\mathrm{d}}$ environment only $81 \%$ flowered, in an average of $108 \mathrm{~d}$ (Table 3 ). Plants initiated flowers at approximately the seventh node under both filter treatments, but under the $\mathrm{N}$ filter, the first flower developed to anthesis at least two nodes sooner than under the $\mathrm{FR}_{\mathrm{d}}$ filter. Thus, the number of initiated but undeveloped buds below the first open flower was significantly higher under the $\mathrm{FR}_{\mathrm{d}}$ filter.

\section{Coreopsis transfer (Expt. 3)}

During the first 2 weeks of the experiment, the average DLI was $11.8 \mathrm{~mol} \cdot \mathrm{m}^{-2} \cdot \mathrm{d}^{-1}$ under the unfiltered, high light environment and $4.3 \mathrm{~mol} \cdot \mathrm{m}^{-2} \cdot \mathrm{d}^{-1}$ under the $\mathrm{N}$ filter. Coreopsis $\times$ grandiflora that received $\geq 2$ weeks of LD with a high DLI developed about two fewer nodes and flowered 11 or $12 \mathrm{~d}$ earlier than plants maintained under the same photoperiod but under the $\mathrm{N}$ or $\mathrm{FR}_{\mathrm{d}}$ filters (Table 4). The $\mathrm{FR}_{\mathrm{d}}$ filter reduced plant height by $21 \%$ regardless of the duration of high light exposure but did not influence any other measured characteristic.

\section{Discussion}

Results demonstrate the variability in how LDP respond to environments deficient in R, FR, and B light. Relative to the five LDP studied, sensitivity of extension growth to $\mathrm{R}$ : FR ratio was 

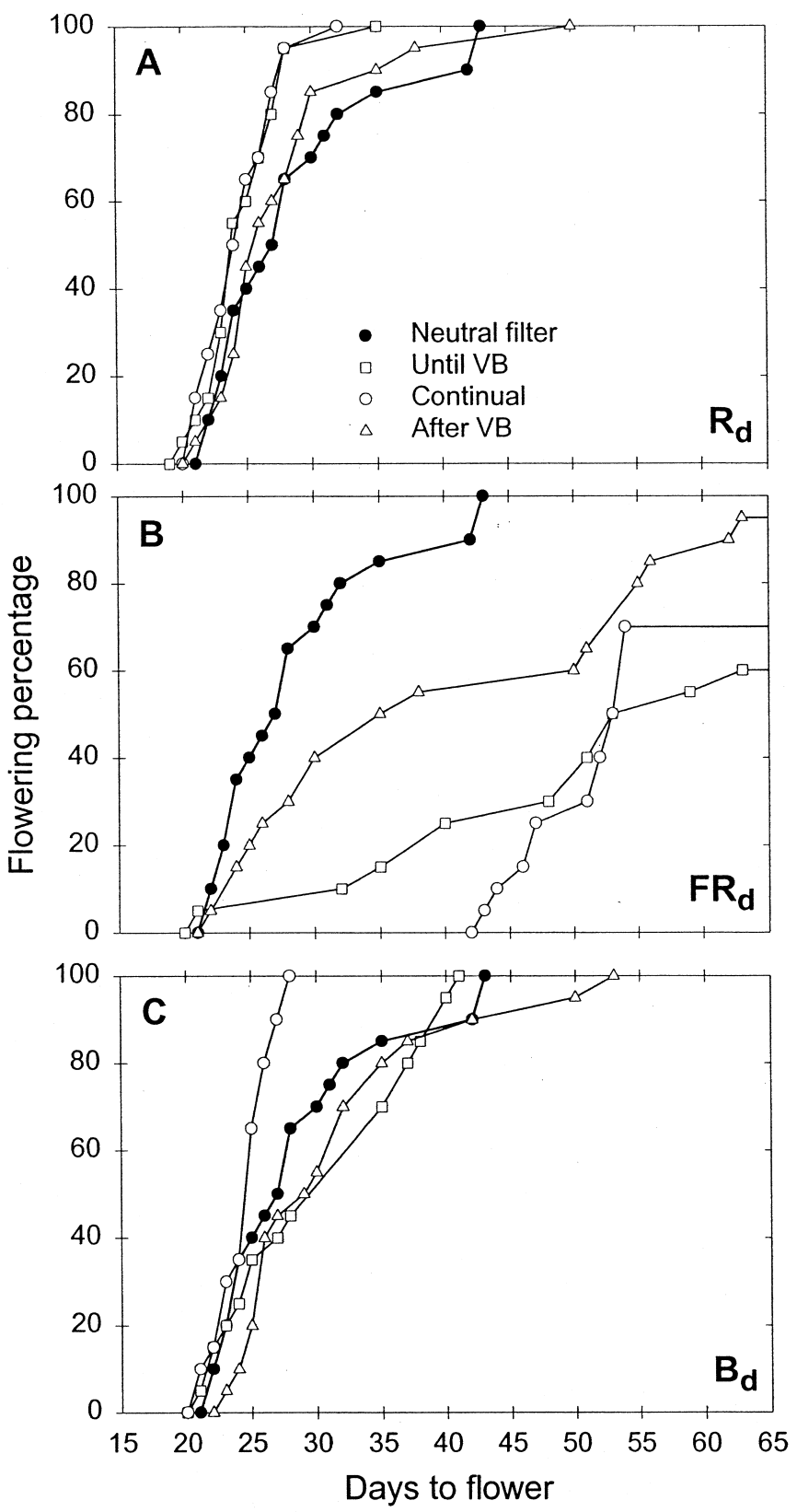

Fig.5(above). Flowering percentage of Viola $\times$ wittrockiana underaneutral filteroralight environment deficient in $(A)$ red $\left(R_{d}, 600\right.$ to $\left.700 \mathrm{~nm}\right),(B)$ far red $\left(\mathrm{FR}_{d}, 700\right.$ to $\left.800 \mathrm{~nm}\right)$, or $(C)$ blue $\left(B_{d}, 400\right.$ to $\left.500 \mathrm{~nm}\right)$ light. Plants were held under the light treatments until visible bud (until VB), continually, or after visible bud (after VB). Plants were under the neutral filter at all other times. A 16-h photoperiod was provided with a combination of sunlight and high-pressure sodium lamps positioned above filters. small in L. $\times$ speciosa, moderate in $P$. sativum and $V . \times$ wittrockiana, and large in $C$. carpatica and $C$. $\times$ grandiflora. Independently, stem extension was promoted in all species under the $B_{d}$ environment, but lack of B light had little or no effect on flowering percentage and time to flower. Although the $\mathrm{R}$ : FR ratio had no effect on flowering time of $L$. Xspeciosa and $P$. sativum, a high R : FR ratio delayed flower initiation in $C$. carpatica and $C$. $\times$ grandiflora and inhibited flower development in $V$. $\times$ wittrockiana.

Although the average DLI was relatively low (Table 1), time to flower of the same cultivars of $C$. carpatica, $C$. $\times$ grandiflora, $L$. $\times$ speciosa, and $V . \times$ wittrockiana was similar with that reported previously using similar temperatures and identical photoperiods (Runkle and Heins, 1998; Runkle et al., 1998, 1999; Whitman et al., 1997). In addition, a high DLI $\left(>6 \mathrm{~mol} \cdot \mathrm{m}^{-2} \cdot \mathrm{d}^{-1}\right)$ was required for complete flowering in $C$. $\times$ grandiflora, since flowering was promoted when plants were provided with $\geq 2$ weeks of high light.

Stem extension in C. carpatica, $C$. $\times$ grandiflora, $P$. sativum, and $V . \times$ wittrockiana showed an inverse linear relationship with a wide band $\mathrm{R}$ : FR ratio or estimated $\mathrm{P}_{\mathrm{fr}} / \mathrm{P}$, similar with that reported in other species (Ritchie, 1997; Smith, 1982, 1994). Narrow band R : FR ratios were not linearly related to stem extension of these species (Fig. 6). However, promotion of stem extension in the B deficient environment did not fit any of the relationships, including the estimated $\mathrm{P}_{\mathrm{fr}} / \mathrm{P}$ that accounts for phytochrome absorption in the $\mathrm{B}$ region. Thus, our data indicate that relating stem extension to $\mathrm{R}: \mathrm{FR}$ ratios or estimated $\mathrm{P}_{\mathrm{fr}} / \mathrm{P}$ is invalid when $\mathrm{B}$ light levels differ significantly from that in the natural environment.

Blue light inhibits extension growth in a variety of plants [e.g., pea, pepper (Capsicum annuum L.), and mustard (Sinapis alba L.)] and tissues (hypocotyls, epicotyls, and stems; Brown et al., 1995; Casal and Smith, 1989; Laskowski and Briggs, 1989; Liscum et al., 1992). Our studies suggest that $B$ light plays a role equal to or greater than that of $\mathrm{R}$ or FR light in mediating stem extension in LDP; internode extension in all five LDP species studied was promoted under the $B_{d}$ filter as well as or better than that under the $R_{d}$ filter. The stem extension responses appear to be independent of phytochrome, since the $\mathrm{R}$ : FR ratio and $\mathrm{P}_{\mathrm{fr}} / \mathrm{P}$ under the $\mathrm{B}_{\mathrm{d}}$ treatment were nearly identical to that under the $\mathrm{N}$ treatment (Table 2). In Arabidopsis and Hyoscyamus, the absorption of B light accelerates flowering(Bagnall

Fig. 6 (below). Stem extension of Campanula carpatica, Coreopsis $\times$ grandiflora, Pisum sativum, and Viola $\times$ wittrockiana relative to that under the far red (FR) deficient filter. Stem length was related to $(\mathbf{A}$ and $\mathbf{B})$ red $(\mathrm{R})$ : $\mathrm{FR}$ ratios and $(\mathbf{C})$ the estimated phytochrome photoequilibria $\left(\mathrm{P}_{\mathrm{fr}} / \mathrm{P} ;\right.$ Sager et al., 1988) under the filter treatments. The R : FR ratios were determined using $(\mathbf{A})$ narrow $(10 \mathrm{~nm})$ and $(\mathbf{B})$ wide $(100 \mathrm{~nm})$ band widths. See Fig. 1 and Table 2 for spectral data. Open symbols represent plants exposed to a neutral filter or light deficient in $\mathrm{R}$ or FR. Closed symbols represent plants exposed to light deficient in blue (400 to $500 \mathrm{~nm}$ ). Each symbol represents the average of 17 to 39 observations for Coreposis, 20 for Pisum, and 40 to 80 for other species.

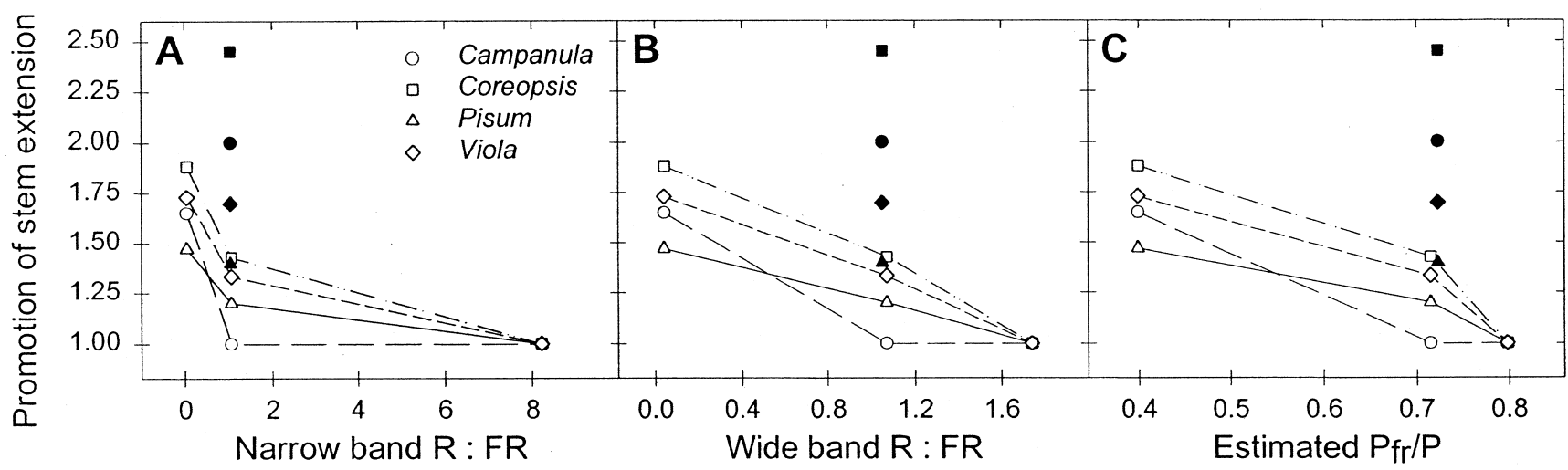


Table 3. Flowering characteristics of Viola $\times$ wittrockiana under the neutral $(\mathrm{N})$ or far red deficient $\left(\mathrm{FR}_{\mathrm{d}}\right)$ filter. Plants were transferred from the $\mathrm{N}$ to the $\mathrm{FR}_{\mathrm{d}}$ filter, or vice versa, following 5, 10, 15, 20, 25, 30,35 , or $40 \mathrm{~d}$. Data were pooled by filter type because transfer time and filter $\times$ transfer time interaction had no significant effect on any measured characteristics.

\begin{tabular}{lcc}
\hline \hline & \multicolumn{2}{c}{ Final environment } \\
\cline { 2 - 3 } Characteristic & $\mathrm{N}$ & $\mathrm{FR}_{\mathrm{d}}$ \\
\hline Flowering (\%) & 100 & $81^{* * * *}$ \\
Axillary flowering (\%) & 4 & $25^{* * * *}$ \\
Days to flower & 83 & $108^{\text {*** }}$ \\
Node of first visible bud & 7.2 & $6.8^{\mathrm{Ns}}$ \\
Node of open flower & 11.7 & $14.1^{* * * *}$ \\
Undeveloped flower buds $^{\mathrm{z}}$ & 4.6 & $7.4^{* * * *}$ \\
\hline
\end{tabular}

${ }^{\mathrm{z}}$ Below the first open flower.

Ns,**** Nonsignificant or significant at $P \leq 0.001$, respectively.

et al., 1996; Guo et al., 1998; Lin et al., 1996; Mozley and Thomas, 1995; Stolwijk and Zeevaart, 1955), but in the five LDP presented herein, B light had little or no effect on flowering percentage or timing. Under the $\mathrm{B}_{\mathrm{d}}$ filter, transmission of $\mathrm{B}$ light was $<10 \%$ of that under the $\mathrm{N}$ filter. However, it is possible that enough $\mathrm{B}$ light penetrated the $B_{d}$ filter to saturate any B-mediated effect on flowering without saturating a B-mediated effect on extension growth.

In LDP, various experiments suggest that flowering is promoted most when $\mathrm{R}$ light (or light creating a high $\mathrm{P}_{\mathrm{fr}} / \mathrm{P}$ ) is delivered at least during the early part of the photoperiod and FR light (or light creating a lower $\mathrm{P}_{\mathrm{fr}} / \mathrm{P}$ ) toward the end (Evans, 1976; KadmanZahavi and Ephrat, 1976; Lane et al., 1965; Thomas and VincePrue, 1997). In our studies, $\mathrm{R}_{\mathrm{d}}$ photoperiods had little or no effect on flowering percentage and timing and node count increase, which suggests that a high $\mathrm{P}_{\mathrm{fr}} / \mathrm{P}$ during the first half of the photoperiod may not necessarily be promotive to flowering in some light-dominant LDP. However, flowering was inhibited in three of the five species studied when the $\mathrm{P}_{\mathrm{fr}} / \mathrm{P}$ was high, and was specific to initiation in $C$. carpatica and $C$. $\times$ grandiflora and development in $V$. $\times$ wittrockiana. Flower initiation was delayed in an $\mathrm{FR}_{\mathrm{d}}$ environment in the LDP snapdragon (Antirrhinummajus L.; van Haeringen et al., 1998). The requirement for FR light for rapid flower development, but not initiation, was reported in Hyoscyamus (Downs and Thomas, 1982). These findings support the hypothesis proposed by Thomas and Vince-Prue (1997) that an FR response, especially toward the end of the photoperiod, is specific to postinductive flower development in some LDP rather than an effect on induction. In other LDP, an FR response is specific to flower initiation. Interestingly, flower development of the SDP chrysanthemum(Dendranthema $\times$ grandiflorum Kitam.) was delayed under weakly inductive N photoperiods compared to the same photoperiod deficient in FR, which suggests that, depending on the timing, FR light can have opposite effects on flower development in SDP and LDP (McMahon, 1999; Rajapakse and Kelly, 1995).

Within the photosynthetically active wave band ( 400 to $700 \mathrm{~nm})$, photons are not equally effective at producing photosynthesis. Red light, especially around $600 \mathrm{~nm}$, is the most efficient wave band, whereas B light is $\approx 80 \%$ as efficient (McCree, 1972; Sager et al., 1988). A model has been developed to quantify the relative quantum efficiency (RQE), which is useful in predicting the photosynthetic capacity of a given light quality (Sager et al., 1988). The RQE was lower (by 13\%) under the $\mathrm{R}_{\mathrm{d}}$ filter and higher (by $5 \%$ ) under the $\mathrm{B}_{\mathrm{d}}$ filter compared with that of the $\mathrm{N}$ filter (Table 2). Flower number of C. carpatica and L. Xspeciosa and DW of $P$. sativum were reduced by $33 \%$ to $54 \%$ under the $\mathrm{R}_{\mathrm{d}}$ filter and increased by $15 \%$ to $37 \%$ under the $\mathrm{B}_{\mathrm{d}}$ filter. Similarly, DW of chrysanthemum was reduced under $\mathrm{R}_{\mathrm{d}}$ films compared to $\mathrm{N}$ filters transmitting a similar PPF (Oyaert et al., 1999). Therefore, differences in flower number and DW among lighting treatments could be at least partially attributed to the different $R Q E$ and suggest that relatively small changes in RQE can have large effects on growth.

Plants absorb most visible light (400 to $700 \mathrm{~nm}$ ) but reflect or transmit most FR light, and thus a low $\mathrm{R}$ : FR ratio is created under a canopy. In response to such an environment, extension growth and flowering are promoted in shade-avoiding species (Smith, 1994). The ecological strategy of the shade-avoidance syndrome is to promote and direct extension growth in an attempt to better harvest available sunlight. In contrast, shade-tolerant species respond to a low $\mathrm{R}$ : FR ratio without a significant change in extension growth. Not surprisingly, in our studies the species most adaptive to shade in the natural environment $(L . \times$ speciosa) was the least responsive to $\mathrm{R}$ : FR ratio, while the shade-avoiding species $C$. carpatica and C. $\times$ grandiflora were sensitive to $\mathrm{R}$ : FR ratios (Armitage, 1989). Light under a canopy is also deficient in B light, and since a $B_{d}$ environment promoted extension growth in all species we studied, an alternative shade-avoiding ecological strategy could be mediated by B light. These potentially redundant shade-avoiding strategies are consistent with studies demonstrating independent, interactive,

Table 4. Flowering responses of Coreopsis $\times$ grandiflora transferred from an unfiltered $16-\mathrm{h}$ photoperiod with supplemental high pressure sodium lamps [providing a high daily light integral (DLI)] to a neutral $(\mathrm{N})$ or far red deficient $\left(\mathrm{FR}_{\mathrm{d}}\right)$ filter.

\begin{tabular}{|c|c|c|c|c|c|}
\hline Parameter & $\begin{array}{c}\text { Flowering } \\
(\%)\end{array}$ & $\begin{array}{l}\text { Days to } \\
\text { flower }\end{array}$ & $\begin{array}{c}\text { Increase in } \\
\text { node no. }\end{array}$ & $\begin{array}{c}\text { Flower } \\
\text { no. }\end{array}$ & $\begin{array}{l}\mathrm{Ht} \\
(\mathrm{cm})\end{array}$ \\
\hline \multicolumn{6}{|l|}{ Weeks at high DLI } \\
\hline 0 & 90 & 65.5 & 8.4 & 9.9 & 25.4 \\
\hline 2 & 95 & 53.5 & 6.3 & 8.2 & 26.5 \\
\hline 3 & 95 & 54.4 & 5.9 & 11.9 & 26.4 \\
\hline 4 & 100 & 53.2 & 6.8 & 14.7 & 26.4 \\
\hline \multicolumn{6}{|l|}{ Final filter environment } \\
\hline $\mathrm{N}$ & 98 & 56.9 & 6.8 & 10.6 & 29.2 \\
\hline $\mathrm{FR}_{\mathrm{d}}$ & 93 & 56.4 & 6.8 & 11.7 & 23.1 \\
\hline \multicolumn{6}{|l|}{ Significance } \\
\hline Weeks high DLI (WHDLI) & & $* * *$ & $* * *$ & $* * *$ & NS \\
\hline Final filter (FF) & & NS & NS & NS & $* * *$ \\
\hline $\mathrm{WHDLI} \times \mathrm{FF}$ & & NS & NS & NS & NS \\
\hline
\end{tabular}


and redundant actions of the B-absorbing and R-and FR-absorbing photoreceptors (cryptochrome and phytochrome, respectively) in Arabidopsis (Casal and Mazzella, 1998; Poppe et al., 1998).

The species in which flowering and extension growth was influenced the most by $\mathrm{R}$ : FR ratios was $V$. $\times$ wittrockiana. Plants under the $\mathrm{R}_{\mathrm{d}}$ filter (e.g., low $\mathrm{R}$ : FR ratio) were strongly apically dominant; stem extension and flowering were promoted, and in nearly all instances, first flowering occurred on the primary stem. In contrast, branching was promoted and flowering was inhibited under the $\mathrm{FR}_{\mathrm{d}}$ filter (e.g., high $\mathrm{R}$ : FR ratio). Of those that flowered under the $\mathrm{FR}_{\mathrm{d}}$ filter, a significant proportion (25\% in Expt. 2) of plants first flowered on an axillary stem (Table 3 ).

In summary, our data illustrate the variability in how light quality influences flowering in LDP and demonstrate that although an $\mathrm{FR}_{\mathrm{d}}$ environment can suppress stem extension, it can also delay flowering in some species. A deficiency in FR light can specifically delay flower initiation in some species (e.g., C. carpatica and $C$. $\times$ grandiflora) and flower development in others (e.g., V. ×wittrockiana). In the former (but not latter) species, plants can be induced to flower under $\mathrm{N}$ photoperiods then transferred to an $\mathrm{FR}_{\mathrm{d}}$ environment to facilitate rapid flowering with reduced stem extension. The filters used reduced, but did not completely eliminate, transmission of certain wavebands of light. However, our results suggest that extension growth can be attributed to a wide (but not narrow) band $\mathrm{R}$ : FR ratio or $\mathrm{P}_{\mathrm{fr}} / \mathrm{P}$, except when the $\mathrm{B}$ component is significantly altered. Therefore, blanket statements are inappropriate when discussing flowering and stem extension responses of LDP to light quality. Currently, we are performing additional studies to determine if various lighting strategies can suppress stem extension in sensitive LDP without an inhibition in flowering. Further research is also merited to determine how B light interacts with the R : FR ratio to regulate extension growth in plants outside the Brassicaceae.

\section{Literature Cited}

Armitage, A.M. 1989. Herbaceous perennial plants. Varsity Press, Athens, Ga. Bagnall, D.J., R.W. King, and R.P. Hangarter. 1996. Blue-light promotion of flowering is absent in hy4 mutants of Arabidopsis. Planta 200:278-280.

Brown, C.S., A.C. Schuerger, and J.C. Sager. 1995. Growth and photomorphogenesis of pepper plants under red light-emitting diodes with supplemental blue or far-red lighting. J. Amer. Soc. Hort. Sci. 120:808-813.

Casal, J.J. and H. Smith. 1989. Effects of blue light pretreatments on internode extension growth in mustard seedlings after the transition to darkness: Analysis of the interaction with phytochrome. J. Expt. Bot. 40:893-899.

Casal, J.J. and M.A. Mazzella. 1998. Conditional synergism between cryptochrome 1 and phytochrome B is shown by the analysis of phyA, phyB, and hy 4 simple, double, and triple mutants in Arabidopsis. Plant Physiol. 118:19-25.

Downs, R.J. and J.F. Thomas. 1982. Phytochrome regulation of flowering in the long-day plant, Hyoscyamus niger. Plant Physiol. 70:898-900.

Evans, L.T. 1976. Inflorescence initiation in Lolium temulentum L. XIV. The role of phytochrome in long day induction. Austral. J. Plant Physiol. 3:207-217.

Guo, H., H. Yang, T.C. Mockler, and C. Lin. 1998. Regulation of flowering time by Arabidopsis photoreceptors. Science 279:1360-1363.

Hayward, P.M. 1984. Determination of phytochrome parameters from radiation measurements, p. 159-173. In: H. Smith and M.G. Holmes (eds.). Techniques in photomorphogenesis. Academic Press, London.

Kadman-Zahavi, A. and E. Ephrat. 1976. Development of plants in filtered sunlight. III. Interaction of the spectral composition of main-light periods with end-of-day red or far red irradiations and with red night interruptions in bolting and flowering of Hyoscyamus niger. Israel J. Bot. 25:203-210.

Kigel, J. and D.J. Cosgrove. 1991. Photoinhibition of stem elongation by blue and red light. Plant Physiol. 95:1049-1056.

Kubota, S., T. Yamato, T. Hisamatsu, S. Esaki, R. Oi, M. Roh, and M. Koshioka. 2000. Effects of red- and far red-rich spectral treatments and diurnal temperature alternation on the growth and development of Petunia. J. Jpn. Soc. Hort. Sci. 69:403-409.
Lane, H.C., H.M. Cathey, and L.T. Evans. 1965. The dependence of flowering in several long-day plants on the spectral composition of light extending the photoperiod. Amer. J. Bot. 52:1006-1014.

Laskowski, M.J. and W.R. Briggs. 1989. Regulation of pea epicotyl elongation by blue light. Plant Physiol. 89:293-298.

Lin, C., M. Ahmad, and A.R. Cashmore. 1996. Arabidopsis cryptochrome 1 is a soluble protein mediating blue light-dependent regulation of plant growth and development. Plant J. 10:893-902.

Liscum, E., J.C. Young, K.L. Poff, and R.P. Hangarter. 1992. Genetic separation of phototropism and blue light inhibition of stem elongation. Plant Physiol. 100:267271.

McCree, K.J. 1972. The action spectrum, absorptance and quantum yield of photosynthesis in crop plants. Agr. Meteorol. 9:191-216.

McMahon, M. 1999. Development of chrysanthemum meristems grown under far red absorbing filters and long or short photoperiods. J. Amer. Soc. Hort. Sci. 124:483-487.

Mozley, D. and B. Thomas. 1995. Developmental and photobiological factors affecting photoperiodic induction in Arabidopsis thaliana Heynh. Landsberg erecta. J. Expt. Bot. 46: 173-179.

Murakami, K., H. Cui, M. Kiyota, Y. Takemura, R. Oi, and I. Aiga. 1996. Covering materials to control plant growth by modifying the spectral balance of daylight. Plasticulture 110:2-14.

Oyaert, E., E. Volckaert, and P.C. Debergh. 1999. Growth of chrysanthemum under coloured plastic films with different light qualities and quantities. Scientia Hort. 79:195-205.

Poppe, C., U. Sweere, H. Drumm-Herrel, and E. Schäfer. 1998. The blue light receptor cryptochrome 1 can act independently of phytochrome A and B in Arabidopsis thaliana. Plant J. 16:465-471.

Rajapakse, N.C. and J.W. Kelly. 1995. Spectral filters and growing season influence growth and carbohydrate status of chrysanthemum. J. Amer. Soc. Hort. Sci. 120:78-83.

Rajapakse, N.C., R.E. Young, M.J. McMahon, and R. Oi. 1999. Plant height control by photoselective filters: Current status and future prospects. HortTechnology 9:618-624.

Ritchie, G.A. 1997. Evidence for red : far red signaling and photomorphogenic growth response in Douglas-fir (Pseudotsuga menziesii) seedlings. Tree Physiol. 17:161-168

Runkle, E.S. and R.D. Heins. 1998. Lighting up pansies. Greenhouse Grower 16(10):60-66.

Runkle, E.S., R.D. Heins, A.C. Cameron, and W.H. Carlson. 1998. Flowering of herbaceous perennials under various night interruption and cyclic lighting treatments. HortScience 33:672-677.

Runkle, E.S., R.D. Heins, A.C. Cameron, and W.H. Carlson. 1999. Cold treatment modifies the photoperiodic flowering response of Lobelia $\times$ speciosa. Scientia Hort. 80:247-258.

Sager, J.C., W.O. Smith, J.L. Edwards, and K.L. Cyr. 1988. Use of spectral data to determine photosynthetic efficiency and phytochrome photoequilibria. Trans. Amer. Soc. Agr. Eng. 31:1882-1889.

Schneider, M.J., H.A. Borthwick, and S.B. Hendricks. 1967. Effects of radiation on flowering of Hyoscyamus niger. Amer. J. Bot. 54:1241-1249.

Shinomura, T., K. Uchida, and M. Furuya. 2000. Elementary processes of photoperception by phytochrome A for high-irradiance response of hypocotyl elongation in Arabidopsis. Plant Physiol. 122:147-156.

Smith, H. 1982. Light quality, photoperception, and plant strategy. Annu. Rev. Plant Physiol. 33:481-518.

Smith, H. 1994. Sensing the light environment: The functions of the phytochrome family, p. 377-416. In: R.E. Kendrick and G.H.M. Kronenberg (eds.). Photomorphogenesis in plants. 2nd ed. Kluwer Academic Publishers, Netherlands.

Stolwijk, J.A.J. and J.A.D. Zeevaart. 1955. Wave length dependence of different light reaction governing flowering in Hyoscyamus niger. Proc. K. Ned. Acad. Wet. Ser. C. 58:386-396.

Thomas, B. and D. Vince-Prue. 1997. Photoperiodism in plants. 2nd ed. Academic Press, London.

van Haeringen, C.J., J.S. West, F.J. Davis, A. Gilbert, P. Hadley, S. Pearson, A.E. Wheldon, and R.G.C. Henbest. 1998. The development of solid spectral filters for the regulation of plant growth. Photochem. Photobiol. 67:407-413.

Warpeha, K.M.F. and L.S. Kaufman. 1989. Blue-light regulation of epicotyl elongation in Pisum sativum. Plant Physiol. 89:544-548.

Whitman, C.M., R.D. Heins, A.C. Cameron, and W.H. Carlson. 1997. Cold treatment and forcing temperature influence flowering of Campanula carpatica 'Blue Clips'. HortScience 32:861-865. 